\title{
ОРГАНІЗАЦІЙНА ПСИХОЛОГІЯ; ЕКОНОМІЧНА ПСИХОЛОГІЯ
}

\author{
УДК 159.922.2:34.08 \\ DOI https://doi.org/10.32840/2663-6026.2019.3-2.26
}

Ю. Л. Вітомський
кандидат психологічних наук

\section{ПСИХОЛОГІЧНІ ОСОБЛИВОСТІ ФОРМУВАННЯ ПОЗИТИВНОГО ЕМОЦІЙНОГО ІНТЕРЕСУ ДО ПРОФЕСІЙНОЇ ДІЯЛЬНОСТІ ПРАЦІВНИКІВ ОХОРОНИ}

Статтю присвячено вивченню психологічних особливостей формування позитивного емоційного інтересу до профресійної діяльності охоронців різної спеціалізації. Актуальність дослідження обумовлюється недостатньою дослідженістю в психології трудової діяльності особливостей поведінки співробітника охорони в умовах профресійної діяльності, оцінка ступеня стійкості емоційної сфрери, а отже, і можливостей вибору диференційованих заходів, спрямованих на профілактику нервових зривів і неуспішних поведінкових реакцій.

Для того щоб співробітник охорони, прагнув до оволодіння спеціальними знаннями, вміннями, навичками і ефрективно вирішував поставлені перед ним завдання, він повинен бути зацікавлений в успішному здійсненні своєї професійної діяльності, що апріорі передбачає ефективну адаптацію до профресійної діяльності. Саме тому важливого значення набуває набуття профресійного інтересу, тобто інтересу до способів розв'язання проблем, які виникають під час охоронної діяльності.

Для формування професійного інтересу високого рівня, який сприяє ефективній адаптації в обраній професії, необхідно створення і впровадження комплексної систематизованої моделі, що сприяє розвиткові п'яти компонентів професійного інтересу: мотиваційного, емоційного, вольового, пізнавального і потребнісно-діяльнісного.

Реалізація комплексної моделі формування професійного інтересу працівників охорони здійснювалася нами в рамках дослідно-експериментальної роботи, яка представляє собою чотири логічно взаємопов'язані блоки: 1) цільовий блок передбачає постановку цілей і завдань дослідно-експериментальної роботи; 2) організаційний блок передбачає організацію дослідного процесу; 3) змістовий блок відображає обсяг компетенцій, якими опановують співробітники в процесі підготовки, а також особистісних якостей, які повинні бути у них сформовані та розвинені; 4) результативний блок включає якісно-кількісний аналіз і інтерпретацію результатів дослідно-експериментальної роботи, їх зіставлення з прогнозованими та бажаними результатами.

Ключові слова: співробітник охорони, охоронне підприємство, професійна діяльність, позитивний емоційний інтерес.

Постановка проблеми. Дослідження психологічних особливостей адаптації охоронників до професійної діяльності, у зв'язку зі зміною завдань і зовнішніх чинників, що визначають цю діяльність, $€$ надзвичайно актуальною проблемою. На сучасному етапі становлення ринкової інфрраструктури в Україні ця професія є вельми затребуваною, попри наявність стресогенних чинників, що впливають на поведінку і діяльність співробітників охоронних фірм. У багатьох випадках професійний стрес пов'язаний з частими явищами агресії, соціально-психологічні причини якої також не достатньо досліджені. Оскільки усунення впливу соціально-психологічних чинників навряд чи можливе в суспільстві, яке понад 28 років перебуває в стані перманентної ціннісно-психологічної кризи, вважаємо за доцільне дослідити психологічні особли- вості адаптації охоронників до професійної діяльності, а відтак і мінімізації негативного впливу на цю діяльність соціально-психологічних чинників. Наукове розв'язання ієї проблеми дало б змогу запропонувати практичні рекомендації, спрямовані на досягнення оптимального пристосування співробітників охоронних фрірм до умов професійної діяльності на конкретному об'єкті, сприяло б досягненню високих результатів і забезпеченню оптимальних можливостей для реалізації потреб особистості охоронника.

Аналіз останніх досліджень і публікацій. Важливі аспекти регуляції психічного стану профресіонала вивчали Блінов О.А. [2], Клімов Є.А. [5] та інші.

Досить вдалі спроби систематизувати вплив екстремальних чинників на професійну діяль- 
ність в екстремальних умовах були зроблені в роботах Кокуна О.М. [6], Кондрюкової В.В. [7], Миронця С.М. [9], Попова В.М., Астапенкової В.М. [11]. Автори вважають, що характер і найменування стресу (емоційний, бойовий, навчальний, авіаційний, спортивний та інші) не просто залежить, але і визначається його змістом. Причинами напруженості автори вважають будь-який емоціогенний чинник, однак виникаючий лише в певних умовах: невідповідність індивідуальних якостей зовнішнім вимогам, непідготовленість, помилки в методах професійного навчання, несприятливі функціональні стани людини, особлива індивідуальна значущість зазначених чинників.

Адаптаційний потенціал особистості в кризових умовах досліджували Коробка Л.М. [8], Гнатюк С.С. [3], Антипенко В.Н., Вишневсьий В.П. [1].

Проблеми формування професійного інтересу майбутніх кваліфрікованих робітників були колом наукового пошуку Романенко Л.В [12].

Закордонні дослідники соціальної адаптації E. Wall, K. Marzal в якості основних адаптаційних ресурсів виділяють соціальні ресурси особи, до яких також відносять допомогу людей одне одному, відчуття належності до спільноти, колективу, соціальну згуртованість [13].

Важливі психологічні аспекти праці охоронника досліджували Каленяк В.П. [4], Половнікова Ж.Ю. [10].

Водночас проведений аналіз літератури дослідження показує, що спеціальних науково обґрунтованих психологічних розвідок розвитку професійного адаптаційного потенціалу працівників охорони та взагалі сектору безпеки підприємств, до цього часу не проведено. Таким чином, виникає наукова проблема: з одного боку, між значною увагою до психологічних проблем професійної адаптації та недостатньою кількістю досліджень в галузі організаційної психології з проблем розвитку адаптаційного потенціалу співробітників сектору охорони підприємств.

Метою даної статті є вивчення психологічних особливостей формування позитивного емоційного інтересу до професійної діяльності охоронців різної спеціалізації.

Виклад основного матеріалу. В сучасному постіндустріальному суспільстві стрімко розвивається світ профресій, фрормуються профресійні норми, правила, вимоги щодо представників будьякого виду професійної діяльності. Згідно з цими вимогами фахівець повинен володіти певними профресійними знаннями, бути компетентним у професійній діяльності.

Для того щоб співробітник охорони, прагнув до опанування спеціальними знаннями, вміннями, навичками та ефективно вирішував поставлені перед ним завдання, він повинен бути зацікавлений в успішному здійсненні своєї професійної діяльності, що, на нашу думку, передбачає ефективну адаптацію до професійної діяльності. Саме тому важливого значення набуває набуття професійного інтересу, тобто інтересу до способів розв'язання проблем, які виникають під час охоронної діяльності.

У контексті нашого дослідження ми спиралися на підходи до формування професійного інтересу до майбутньої діяльності, окреслені Романенко Л.В. [12]. Однак ми кілька поглибили дане поняття щодо предмета дослідження - професійного інтересу співробітників охорони. Таким чином, під професійним інтересом співробітників охорони ми розуміємо інтегративну характеристику особистості, що містить мотивоване, емоційне, пізнавальне і ціннісно-цільове ставлення особистості до професійної діяльності. Це ставлення вирізняється вольовою активністю в розвитку здібностей і професійно-особистісних якостей співробітника підрозділу охорони та проявляється в прагненні суб'єкта до активної залученості в процес діяльності та самореалізації в ній.

Для формування профессійного інтересу високого рівня, який сприяє ефеективній адаптації в обраній профресії, необхідно створення і впровадження комплексної систематизованої моделі, що сприяє розвиткові п'яти компонентів професійного інтересу: мотиваційного, емоційного, вольового, пізнавального і потребнісно-діяльнісного.

Для розробки нашої моделі нам необхідно визначити їі структуру та основні компоненти: мету, завдання, зміст, методи, засоби, умови, фооми взаємодії, а також досягнуті водночас результати. На нашу думку, найбільш прийнятною $є$ структура, яка ґрунтується на виділенні основних компонентів процесу формування професійного інтересу співробітників охорони в процесі морально-психологічної підготовки: мета - організаційні форми зміст - результат.

Відповідно реалізація комплексної моделі формування професійного інтересу працівників охорони здійснювалася нами в рамках дослідно-експериментальної роботи, яка являє собою чотири логічно взаємопов'язані блоки: 1) цільовий блок передбачає постановку цілей і завдань дослідно-експериментальної роботи; 2) організаційний блок передбачає організацію дослідного процесу; 3) змістовий блок відбиває обсяг компетенцій, якими опановують співробітники в процесі підготовки, а також особистісних якостей, які повинні бути у них ссрормовані та розвинені; 4) результативний блок включає якісно-кількісний аналіз і інтерпретацію результатів дослідно-експериментальної роботи, їх зіставлення з прогнозованими та бажаними результатами.

Одним зі складників процесу формування професійного інтересу співробітників охорони $€$ етап формування емоційного компонента. 
Виникнення професійного інтересу співробітника охорони починається з прояви позитивних емоцій у суб'єкта щодо праці в секторі охорони підприємства. Емоції, являючись фоном діяльності особистості, служать одним з головних чинників, що визначають успішність виконання професійної діяльності. Позитивні емоції щодо професії служать джерелом в прояві мотивів вибору професії (мотиваційний компонент), сприяють особистісному обґрунтуванню професійного вибору.

Вельми продуктивним нам видається поєднання емоційного і вольового компонентів в діяльності людини, оскільки вольовий компонент служить регулятором в емоційних переживаннях. 3 іншого боку, стійкий професійний інтерес, активізуючи всі психічні властивості особистості, допомагає долати труднощі, сприяє вихованню вольових якостей особистості, допомагає розставити ціннісні орієнтири співробітників охорони на даному етапі самовдосконалення і професійної адаптації.

В емоційному компоненті закладено позитивне ставлення до професійної діяльності у секторі охорони, впевненість у правильності ії вибору, задоволеність вибором. Зазначені позиції, таким чином, неможливі без внутрішнього емоційного комфорту і сприятливого соціально-психологічного клімату в колективі охоронників. В даній ситуації $€$ ключовою роль безпосереднього керівника, який відповідає за професійну діяльність охоронника. Його завданням, насамперед, $€$ оцінка і коригування діяльності підлеглого щодо іiі ефективності та задоволення матеріально-побутових потреб і запитів охоронників, організації їх відпочинку. Відомо, що особливої уваги розв'язання вказаних проблем стосується охоронників, які працюють за так званим «вахтовим» методом роботи, що передбачає значну віддаленість від постійного місця проживання охоронника.

Формування позитивного соціально-психологічного клімату в підрозділі $€$ іншим важливим напрямом роботи безпосереднього керівника, оскільки сприятлива психологічна атмосфера і душевний комфорт сприяють більш якісному виконанню охоронником покладених на нього службових обов'язків.

Оскільки основна частина роботи співробітника охорони нерозривно пов'язана 3 недопущенням протиправної діяльності щодо працівників підприємства та майна, а відтак з обов'язковим спілкуванням з потенційними та дійсними порушниками режиму охорони об'єкта, з усіма притаманними їм змінами свідомості та моралі, кожному охороннику потрібна велика емоційна віддача за умови дефіциту позитивних вражень. Крім негативного впливу такого професійного середовища, стресогенним чинником $€$ сувора регламентація робочого часу при нереальності термінів виконання поставленого завдання, оперативність прийняття рішень, недолік умов самовираження, професійного вдосконалення, напруженість і конфліктність в міжособистісних відносинах з колективом підприємства, вкладання в роботу великих особистісних ресурсів при нестачі морального і матеріального визнання важливості своєї праці.

Таким чином, третім важливим напрямом роботи безпосереднього керівника і чинником, що сприяє формуванню емоційного компонента професійного інтересу, стає розвиток психологічної грамотності як керівництва, так і рядових співробітників охорони.

Вказаний напрям роботи пропонуємо реалізувати за двома векторами. Першим компонентом цього блоку $\epsilon$ розвиток психологічної грамотності, якому сприяють психологічні модулі, що розглядаються на групових заняттях 3 морально-психологічної підготовки охоронників. Сюди входять, зокрема, такі теми, як «Навчання навичкам психічної саморегуляції», «Конфлікт як невіддільна частина діяльності відділу охорони», «Агресивність і тривожність охоронника як прояв професійної деформації», «Емоційне вигорання охоронника як чинник виникнення внутрішньо особистісного конфрлікту» та інше.

Іншим важливим компонентом $є$ індивідуальне психологічне консультування із залученням професійного психолога, на якому опрацьовуються індивідуальні запити співробітників охорони та за необхідності здійснюється корекція психічного стану особи.

Означена вище модель формування позитивного емоційного професійного інтересу до професійної діяльності була нами реалізована в охоронному підприємстві «Альфа-ПреміумГруп» (м. Київ). Працівники охорони вказаного підприємства були поділені на контрольну та експериментальну групи. Результати впровадження моделі наведемо у таблиці 1. Як бачимо, кількість співробітників, які демонструють низький $(27,45 \%)$ і середній $(33,87 \%)$ рівні розвитку емоційного компонента професійного інтересу, на початку експерименту впала до 4,84\% і 16,14\% відповідно. Водночас в процесі цілеспрямованого психолого-педагогічного впливу число співробітників, що належать до вище середнього $(46,76 \%)$ і високого (32,28\%) рівня розвитку даного компонента, збільшилася (до експерименту 29,08\% і 9,65\% відповідно).

Відтак значно підвищився рівень психологічної адаптації співробітників охорони до умов професійної діяльності після впровадження моделі формування позитивного емоційного інтересу до професійної діяльності, що підтверджують дані діагностичного дослідження, проведеного після експериментального впливу. Зокрема, кількість співробітників охорони, що належать до вище 
2019 р., № 3, T. 2.

Таблиця 1

Порівняння сформованості позитивного емоційного компонента охоронців підприємства «Альфа-Преміум-Груп»

\begin{tabular}{|l|c|c|l|c|c|}
\hline \multicolumn{2}{|c|}{ Емоційний компонент, до експерименту, \% } & \multicolumn{2}{c|}{ Емоційний компонент, після експерименту, \% } \\
\hline Рівні & ЕГ & КГ & Рівні & \multicolumn{2}{|c|}{ КГ } \\
\hline Високий & 9,65 & 12 & Високий & 32,28 \\
\hline Вище середнього & 29,08 & 32 & Вище середнього & 46,76 \\
\hline Середній & 33,84 & 25 & Середній & 16,14 & 31 \\
\hline Низький & 27,45 & 31 & Низький & 32 & 14 \\
\hline Всього & 100 & 100 & Всього & 100 \\
\hline
\end{tabular}

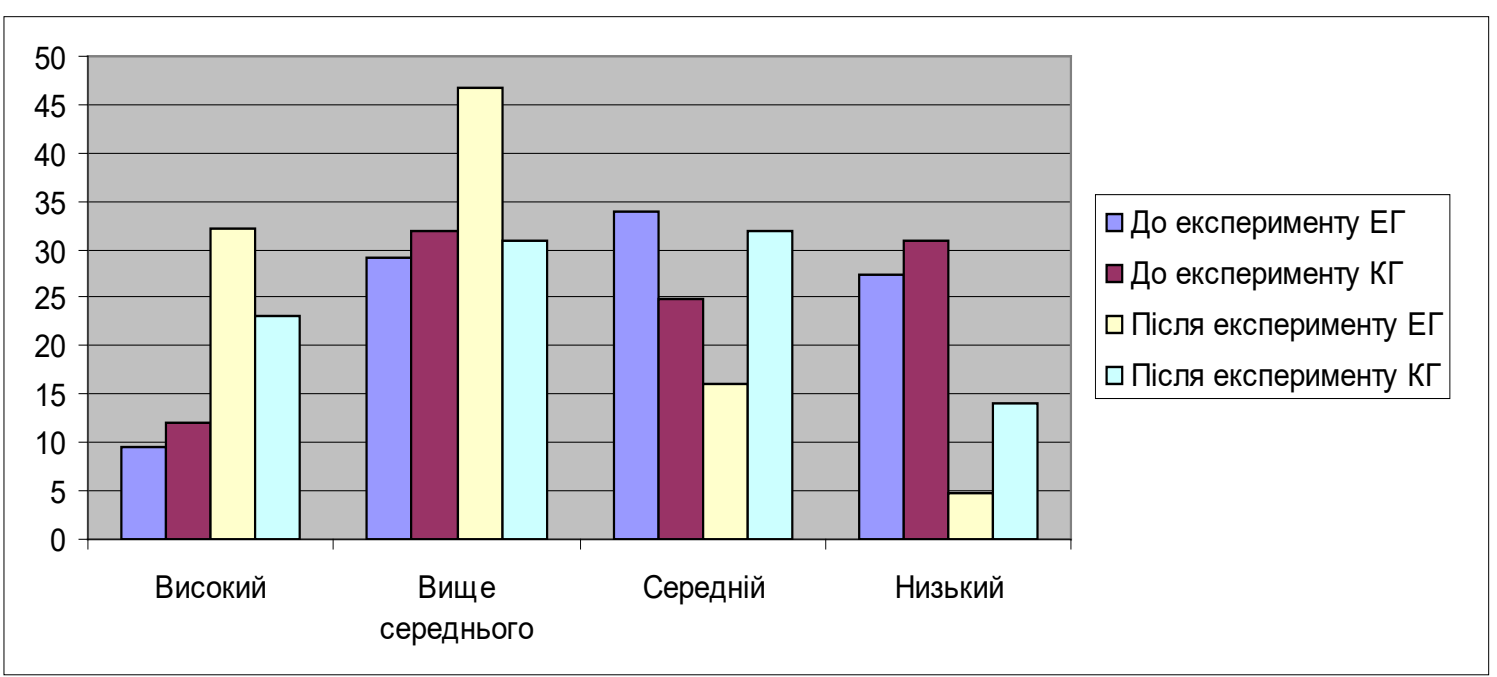

Рис. 1. Сформованість позитивного емоційного компонента охоронців підприємства «Альфа-Преміум-Груп»

середнього та високого рівня емоційного компонента професійного інтересу, в контрольній групі нижче, ніж в експериментальній, на 15,76\% і 9,28\% відповідно.

Крім того, рівень психологічної готовності, а значить, здатність успішно виконувати завдання професійної діяльності, пов'язані з міжособистісними стосунками, застосування навичок психологічної саморегуляції для оптимізації свого психологічного стану також підвищився після цілеспрямованого психолого-педагогічного впливу. Результати експериментальної роботи наочно зображено на рисунку 1.

Аналіз даних, отриманих під час впровадження моделі формування позитивного емоційного інтересу до професійної діяльності, зокрема його емоційного компонента, свідчить про те, що в експериментальній групі відбулися позитивні зміни, оскільки в ній була апробована модель і реалізований комплекс умов формування професійного інтересу співробітників охорони.

Висновки. Таким чином, можна зробити висновок, що заявлений механізм формування позитивного емоційного інтересу до професійної діяльності у співробітників охорони є досить ефективним і закладає основу для подальшої успішної професійної самореалізації співробітника як в рамках морально-психологічної підготовки, так і поза нею.

\section{Література:}

1. Антипенко В.Н., Вишневский В.П. Прогностическое моделирование системы педагогического руководства процессом подготовки учащейся молодёжи к профессиональной адап тации в современных условиях // Молодёжь, труд, профрессия: Материалы междунар. науч. практ. конф. в г. Херсоне. В 2-х частях. Ч. І. Херсон, 1993. С. 20-25.

2. Блінов О.А. Психологія праці : Курс лекцій. Кив : КиМУ, 2009. 269 с.

3. Гнатюк С.C. Проблема соціально-економічної адаптації у психологічній науці. Актуальні проблеми психологічної та соціальної адаптації в умовах кризового суспільства: матеріали III Всеукраїнського науково-практичного круглого столу (6 березня 2018 року) ; за заг. ред. О.Г. Льовкіної, Р.А. Калениченка. Ірпінь : Університет державної фіскальної служби України, 2018 . С. 226-229.

4. Каленяк В.П. Приватна охоронна діяльність : зарубіжний досвід та можливості його використання в Україні. Журнал-каталог “Персонал”. 2007. № 5. URL: http://www.personal.in.ua/

5. Климов Е.А. Развивающийся человек в мире профессий. Моск. гос. ун-т им. М.В. Ломоносова, Обнинский гор. психол. центр «Детство». Обнинск : изд-во «Принтер», 1993. 57 с. 
6. Кокун О.М. Оптимізація адаптаційних можливостей людини : психофізіологічний аспект забезпечення діяльності : Монографія. Київ : Міленіум, 2004. 265 с.

7. Кондрюкова В. В. Адаптація до професійної діяльності : соціально-психологічний аспект. Правничий вісник Університету «КРОК». 2011. Вип. 9.

8. Коробка Л.М. Адаптаційний потенціал як чинник успішної адаптації особи до кризових умов. Актуальні проблеми психологічної та соціальної адаптації в умовах кризового суспільства:матеріали III Всеукраїнського науково-практичного круглого столу (6 березня 2018 року); за заг. ред. О.Г. Льовкіної, Р.А. Калениченка. Ірпінь : Університет державної фріскальної служби України, 2018. С. 36-41.

9. Миронець С.М. Теоретичні підходи психологічного забезпечення аварійно-рятувальних підрозділів МНС України. Збірник наукових праць Інституту психології ім. Г.С. Костюка
АПН України / За ред. Максименка С.Д. Київ : «ГНОЗІС», 2002, Т. IV, ч. 5. С. 166-172.

10. Половникова Ж.Ю. Формирование психологической готовности сотрудников охраны к осуществлению профессиональной деятельности : дис. ... кандидата психол. Наук ; Университет внутренних дел. Харків. 1998. 217 с.

11.Попов В.М., Астапенкова В.М. Психологічні особливості вивченої безпорадності працівників ДСНСУ. Проблеми екстремальної та кризової психології. 2014. Вип. 15. С. 214-221.

12.Романенко Л.В. Аналіз дослідженості проблеми формування профресійного інтересу майбутніх кваліфікованих робітників у психолого-педагогічній літературі. Вісник Національної академії Державної прикордонної служби України. 2014. Вип. 4. С. 20-25.

13.Wall E., Marzall K. Adapt ive Capacity for Climate Change in Canadian Rural Communities. Local Environment. 2006. No. 11 (4). P. 373-397.

\footnotetext{
Vitomskyi Yu. L. Psychological features of formation of positive emotional interests to professional activity of workers of protection

The article is devoted to the study of psychological peculiarities of the formation of positive emotional interest in the professional activity of guards of different specialization. The urgency of the study is conditioned by insufficient research in the psychology of the work activity of the behavior of the security guard in the conditions of professional activity, the assessment of the degree of stability of the emotional sphere, and, consequently, the possibility of choosing differentiated measures aimed at preventing nerve disruptions and unsuccessful behavioral reactions.

In order for a security guard to seek special skills, abilities and skills and effectively solve his tasks, he must be interested in the successful pursuit of his professional activities, which a priori involves effective adaptation to professional activities. That is why the acquisition of professional interest, ie, interest in ways to solve problems that arise during the security activity, becomes of great importance.

In order to form a high-level professional interest that promotes effective adaptation in the chosen profession, it is necessary to create and implement a complex systematized model that promotes the development of five components of professional interest: motivational, emotional, volitional, cognitive, and non-operational.

The implementation of a comprehensive model for the formation of the professional interest of security guards was carried out by us within the framework of experimental and experimental work, which represents four logically interconnected blocks: 1) the target block envisages the setting of goals and objectives of experimental and experimental work; 2) the organizational unit provides for the organization of the research process; 3) the content unit reflects the amount of competencies that are learned by the staff in the process of preparation, as well as the personal qualities that they must be formed and developed; 4) the resultant block includes qualitative-quantitative analysis and interpretation of the results of experimental and experimental work, their comparison with the predicted and desired results.
}

Key words: guardian, security company, professional activity, positive emotional interest. 